\title{
Protective and therapeutic role of mango pulp and eprosartan drug and their anti-synergistic effects against thioacetamide-induced hepatotoxicity in male rats
}

\author{
Nadia Zaki Shaban ${ }^{1}$ (1) $\cdot$ Mohammad Mohammad Zaki ${ }^{1,2} \cdot$ Fayed Koutb $^{3} \cdot$ Ahmed Alaa Abdul-Aziz $^{4}$. \\ Ashraf Abdul-Hamid Elshehawy ${ }^{2} \cdot$ Hany Mehany ${ }^{2}$
}

Received: 25 September 2021 / Accepted: 20 February 2022 / Published online: 4 March 2022

(c) The Author(s) 2022

\begin{abstract}
The present study was done to evaluate the protective and therapeutic role of mango pulp (M), eprosartan drug (E), and their co-administration (EM) against hepatotoxicity induced by thioacetamide (T). Seven groups of rats were prepared as follows: the control (C) group (normal rats), $\mathbf{T}$ group (the rats were injected with T), T-M group (the rats were injected with $\mathrm{T}$, and then treated with M), T-E group (the rats were injected with T, and then treated with E), T-EM group (the rats were injected with T, and then treated with $\mathrm{E}$ and $\mathbf{M}$ ), M-TM-M group (the rats were administered with $\mathrm{M}$ before, during, and after $\mathbf{T}$ injection), and $\mathbf{M}$ group (the healthy rats were administered with $\mathbf{M}$ only). Firstly, the characterizations of $\mathbf{M}$ were determined. Also, the markers of hepatic oxidative stress [malondialdehyde (MDA) and glutathione (GSH) levels and the activities of superoxide dismutase (SOD), glutathione peroxidase (GPx), and glutathione reductase (GSR)], inflammation and fibrosis [(tumor necrosis factor- $\alpha$ (TNF- $\alpha$ ) and platelet-derived growth factor-BB (PDGF-BB) levels and gene expression of transforming growth factor-beta $\left(\mathrm{TGF}-\beta_{1}\right)$ ], and liver functions and microscopic examination were evaluated. The present results revealed that $\mathrm{M}$ contains $419 \pm 1.04 \mu \mathrm{g}$ total phenolics as gallic acid equivalent and $6.8 \pm 0.05 \mu \mathrm{g}$ total flavonoids as quercetin equivalent. The analysis of phenolics and flavonoids showed the presence of chlorogenic, caffeic, 2,5-dihydroxy benzoic, 3,5-dicaffeoylquinic, 4,5-dicaffeoylquinic, tannic, cinnamic acidS, and catechin, phloridzin, and quercetin with different concentrations. Also, M contains various minerals with different concentrations involving potassium, calcium, magnesium, sodium, iron, copper, zinc, and manganese. The current results showed that the total antioxidant capacity of $1 \mathrm{~g}$ of $\mathrm{M}$ was $117.2 \pm 1.16$ as $\mu \mathrm{g}$ ascorbic acid equivalent. Our biochemical studies showed that all treatments significantly reduced T-induced hepatotoxicity and liver injuries, as the oxidative stress and inflammatory and fibrotic markers were diminished where MDA level and the activities of GST, GSSG, and GR were decreased when compared with T group. In contrast, GSH level and the activities of SOD and GPx and GSH/GSSG ratio were increased. In addition, TNF- $\alpha$ and PDGF-BB levels were reduced, and the gene expression of TGF- $\beta 1$ was down-regulated. Consequently, the liver functions were significantly
\end{abstract}

Responsible Editor: Lotfi Aleya

\section{Highlights}

- Thioacetamide (T) induced oxidative stress inflammation and

fibrosis in the liver.

- Mango pulp (M) treatment reduced oxidative stress and improved liver function.

- M or eprosarta (E) or ME treatment reduced liver fibrosis as

TNF- $\alpha$, PDGF-BB, and TGF- $\beta 1$ were decreased.

- M or E has antioxidant, anti-inflammatory, and anti-fibrotic activities.

- Presence of anti-synergistic effect between M and E.

- M administration of healthy rats for 12 weeks has no side effect.

- Chemical analysis showed that M is rich in phenolics, flavonoids, and minerals.

Extended author information available on the last page of the article 
improved. In conclusion, each $\mathbf{E}, \mathbf{M}$, and $\mathbf{E M}$ has a therapeutic effect against T-induced hepatotoxicity via the reduction of the OS, inflammation, and fibrosis. Unfortunately, treatment with $\mathbf{M}$ and $\mathbf{E}$ simultaneously revealed the less effectiveness than the treatment with $\mathbf{M}$ or $\mathbf{E}$ demonstrates the presence of anti-synergistic effect between them. Additionally, M-TM-M treatment showed a better effect than T-M treatment against T-induced hepatotoxicity revealing the prophylactic role of $\mathbf{M}$. The administration of healthy rats with $\mathbf{M}$ for 12 weeks has no side effect.

Keywords Mango pulp $\cdot$ Phenolic and flavonoid compounds $\cdot$ Eprosartan $\cdot$ Hypertension $\cdot$ Thioacetamide $\cdot$ Rat hepatotoxicity $\cdot$ Oxidative stress $\cdot$ Hepatic inflammation $\cdot$ Liver fibrosis

\section{Introduction}

Liver has many metabolic, storing, and secretory functions. It secretes bile; forms blood clotting factors; metabolizes carbohydrates, proteins, and fats; stores vitamins, glycogen, and other substances; cleans blood from wastes and toxic matter; and removes old red blood cells (Koolman and Röhm 2005; Rodes et al. 2008). So, the liver is an important target of the toxicity of drugs and xenobiotics through generation of reactive oxygen species (ROS) and reactive nitrogen species (RNS) leading to the oxidative stress (OS) (Jaeschke et al. 2002). ROS and RNS in the hepatocytes are produced by some metabolic reactions such as in the process of mitochondrial oxidative phosphorylation or they may be produced from catabolism of xenobiotic compounds such as $\mathrm{CCl}_{4}$ and $\mathrm{T}$ (Shaban et al. 2021b, 2022). Cellular antioxidant defense system consists of enzymatic and non-enzymatic factors that maintain cellular redox homoeostasis. Enzymatic factors include superoxide dismutase (SOD), glutathione reductase (GSR), glutathione-S-transferase (GST), and glutathione peroxidase (GPx), while non-enzymatic involving reduced glutathione (GSH), carotenoids, polyphenols, and vitamins (Shaban et al. 2013, 2014, 2016a, b). The OS can occur, when ROS production overcomes the cellular antioxidant defense system whether via an increase in its production or a decrease in the cellular antioxidant ability (Friedman 1999; Saed et al. 2017). The OS performs in direct or indirect ROS-mediated damage of proteins, nucleic acids, and lipids, and has been implicated in diabetes, atherosclerosis, neurodegeneration, and carcinogenesis (Ray et al. 2012).

Thioacetamide $(\mathrm{T})$ is known to produce marked hepatotoxicity in the exposed animals (Palacios et al. 2008). It is metabolized in the liver into active products, thioacetamide-S-oxide and thioacetamide-S,S-dioxide, which cause OS (Akhtar and Sheikh 2013). OS causes liver inflammation through the immune cells activation and production of pro-inflammatory and fibrotic cytokines such as transforming growth factor-beta 1 (TGF- $\left.\beta_{1}\right)$, platelet-derived growth factor-BB (PDGF-BB), and tumor necrosis factor- $\alpha$ (TNF- $\alpha$ ) (Friedman 1999; Saed et al. 2017; Shaban et al. 2017).

The expressing chemotherapy has come to point nonspecific usage of intracellular poisons to suppress mitosis (cell division) or encourage DNA damage, which is why inhibition of DNA reform can increase chemotherapy. Many of the side impacts of chemotherapy can be traced to deterioration of normal cells which divide quickly consequently sensitive to anti-mitotic drugs (Rajman et al. 2018). In contrast, the medicinal plants have been used as a natural source of biologically active compounds with beneficial effects, no or less side effects and environmentally benign, which can be used to improve human health and their uses are increasingly recognized to prevent and treat many diseases (Hesari et al. 2021). Fruits are rich in phytochemicals that have been investigated for their potential health benefits. As a rich source of different biologically active compounds, mango (Mangifera indica) is an excellent example (Ma et al. 2011). Mango contains polyphenolics, flavonoids, and A and $\mathrm{C}$ vitamins. In addition, it contains some minerals which play a vital role in the body (Ma et al. 2011; Lauricella et al. 2017). Angiotensin II (Ang II) acts systemically to regulate blood pressure, electrolytes, and water homeostasis, through the two main receptors $\mathrm{AT}_{1}$ and $\mathrm{AT}_{2}$ (Forrester et al. 2018). Locally, it increases profibrogenic effects, inflammatory cells recruitment, cellular proliferation, and accumulation of extracellular matrix components through increasing secretion and activation of TGF- $\beta_{1}$ via $\mathrm{AT}_{1}$ activation. Eventually, this leads to tissue injury (Forrester et al. 2018).

Eprosartan mesylate drug (E, Fig. 1) is a dicarboxylic acid, a member of the class of imidazoles and thiophenes (Tenero et al. 1998). It is a competitive and reversible angiotensin II receptor antagonist with anti-hypertensive property (Frishman et al. 2005). It blocks the binding of angiotensin II to $\mathrm{AT}_{1}$ receptor in vascular smooth muscle, that way blocking the principal action of angiotensin II on the renin-angiotensin system leading to vascular dilatation (WONG et al. 2000). $\mathrm{E}$ is not metabolized by the cytochrome P450 system. It is mainly eliminated as unchanged drug. Less than $2 \%$ of an oral dose is excreted in the urine as an acyl glucuronide of $\mathbf{E}$ (Frishman et al. 2005).

In the current study, we evaluated the therapeutic effect of mango pulp (M), E, and their co-administration against T-induced hepatotoxicity in rats. The study focused on the determination of the markers of OS, inflammation, and fibrosis in the liver and liver functions. Also, liver microscopic examination was done. The phytochemical compositions of $\mathbf{M}$ especially phenolic and flavonoid contents and minerals were evaluated. 


\section{Material and methods}

\section{Chemicals}

PDGF-BB and TNF- $\alpha$ ELISA kits were purchased from, R \& D Systems, USA, and eBioscience Bender MedySystems $\mathrm{GmbH}$, respectively. Isolate II RNA mini kit and quantitative real-time polymerase chain reaction (qRT-PCR) kit (Sensifast SYBR No-ROX one step kit) were purchased from Bioline, London. TGF-ß1 and glyceraldehyde 3-phosphate dehydrogenase (GAPDH) primers were purchased from Bio basic Inc., Canada. T and E were purchased from Oxford Lab Chem, India, and Abbott Healthcare SAS, France, respectively. Gallic acid, ascorbic acid, and quercetin were purchased from Sigma-Aldrich, USA. Kits for alanine transaminase (ALT), aspartate transaminase (AST), gamma-glutamyl transpeptidase (GGT), bilirubin, albumin, total protein (TP), urea, and creatinine were purchased from spectrum diagnostics, Egypt. Kits of SOD, GSH, GST, and malondialdehyde (MDA) were purchased from Biodiagnostic, Egypt. Kit for assays of GPx was obtained by Gentaur's kits, Belgium. Kit of GSR was purchased from Cayman's kits, USA.

\section{Fruit collection, extract preparation, and characterization}

Fruit collection: Mango fruit (Mangifera indica L., family Anacardiceae), Langra cultivar, was obtained during the month of September 2014 from a local market at Alexandria, Egypt. The healthy fruits of uniform size and appearance were washed, and the pulp of each fruit was cut and stored at $-20{ }^{\circ} \mathrm{C}$ until used.

Extract preparation: The extract was prepared according to the procedure of Kim et al. (2010), where mango pulp (M) was lyophilized for 2 days and ground and the powder was extracted with 5 volumes (w/v) of $80 \%$ ethanol by sonication for 3 days at room temperature. The extract was filtered, and the filtrate was concentrated using rotatory evaporator (Heidolph Hei-VAP Platinum) at $40{ }^{\circ} \mathrm{C}$ and lyophilized and stored at $-80{ }^{\circ} \mathrm{C}$ until used.

\section{Total phenolic and flavonoid contents in mango pulp}

The total phenolic content was determined, using gallic acid as standard (Taga et al. 1984). In brief, $100 \mu \mathrm{l}$ Folin-Ciocalteau reagent and $2 \mathrm{ml}$ of $2 \% \mathrm{Na}_{2} \mathrm{CO}_{3}$ were added to $100 \mathrm{mg}$ of the extract and incubated for $2 \mathrm{~h}$ at room temperature. The absorbance of the resulting blue color was measured at 750 $\mathrm{nm}$. The total phenolic content was expressed in milligrams of gallic acid equivalents per gram $\mathrm{M}$.

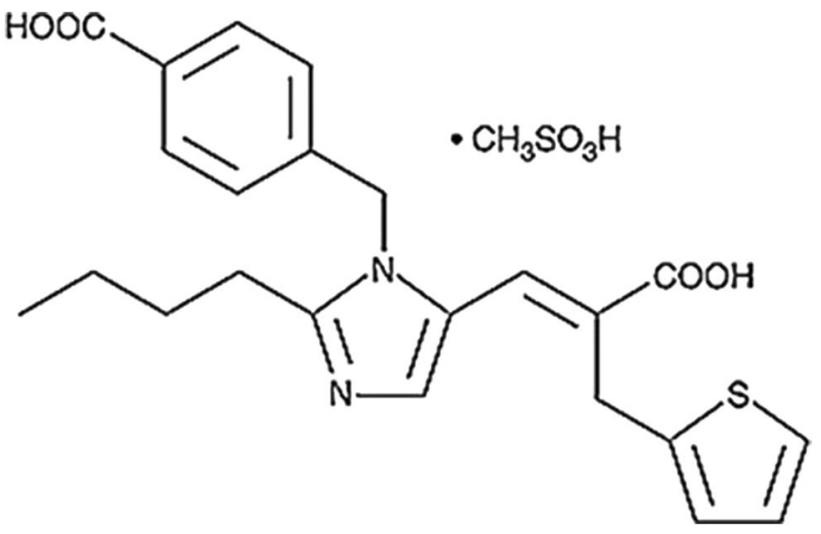

Fig. 1 Chemical structure of eprosatan mesylate

Total flavonoid content was determined, using quercetin as standard (Zou et al. 2004). Briefly, $0.5 \mathrm{~g}$ of the extract was solubilized in $2 \mathrm{ml}$ of distilled water and $0.15 \mathrm{ml}$ of $5 \%$ sodium nitrite solution and incubated at room temperature for $6 \mathrm{~min}$. Then, $0.15 \mathrm{ml}$ of $10 \%$ aluminum chloride solution was added and left to stand for $6 \mathrm{~min}$, followed by adding 2 $\mathrm{ml}$ of $4 \% \mathrm{NaOH}$ solution to the mixture. The mixture was made up to $5 \mathrm{ml}$ with ethanol. The absorbance was measured at $510 \mathrm{~nm}$ after incubation for $15 \mathrm{~min}$. The total flavonoid content was expressed in milligrams of quercetin equivalents per gram $\mathrm{M}$

\section{Analysis of phenolic and flavonoid using high-performance liquid chromatography (HPLC)}

Phenolic and flavonoid were analyzed by HPLC using standard phenolic and flavonoid compounds. In brief, $200 \mathrm{mg}$ of the extract was dissolved in $1 \mathrm{ml}$ of $80 \%$ ethanol to prepare extract solution, where $20 \mu \mathrm{l}$ of it was analyzed using Eclipse XDB-C18 $(5 \mu \mathrm{m}, 4.6 \times 150 \mathrm{~mm})$ column. The mobile phase was consisted of $1 \%(\mathrm{v} / \mathrm{v})$ formic acid in aqueous solution: acetonitrile: 2-propanol (70:22:8), $\mathrm{pH} 2.5$; at $0.75 \mathrm{ml} / \mathrm{min}$ flow rate, UV detection at $320 \mathrm{~nm}$; Agilent technologies $1200 \mathrm{~S}$.

\section{Mango pulp total antioxidant capacity}

It was determined by phosphomolybdenum method of Prieto et al. (1999) using ascorbic acid as standard and expressed in terms of ascorbic acid equivalent, where $300 \mu$ l of the ethanolic extract solution, which prepared as mentioned above, was mixed with $2.7 \mathrm{ml}$ of the reagent solution $(0.6 \mathrm{M}$ sulfuric acid, $28 \mathrm{mM}$ sodiumphosphate, and $4 \mathrm{mM}$ ammonium molybdate). For the blank, $0.3 \mathrm{ml}$ methanol was mixed with $2.7 \mathrm{ml}$ of the reagent. The absorbance of the sample was measured at $695 \mathrm{~nm}$. 


\section{Mango pulp minerals contents}

The minerals in $\mathrm{M}$ were determined according to the method of Ajai et al. (2014) using flame atomic absorption spectroscopy (Avanta $\Sigma$ GBC GF 3000), where a standard solution containing a known concentration of the metal of interest is aspirated into the burner (air/acetylene). Briefly, $\mathrm{M}$ was homogenized well in two volumes (w/v) of $70 \%$ nitric acid in a beaker and the homogenate was heated at $90{ }^{\circ} \mathrm{C}$ on a hot plate in a fume hood for $1 \mathrm{~h}$. Then, it was allowed to cool, filtered, and then diluted to $50 \mathrm{ml}$ with distilled water and stored in a polyethylene container until analysis.

\section{Animals}

Seventy healthy male Sprague-Dawley rats weighing from 90 to $100 \mathrm{~g}$ with age of about 3 months were obtained from the Medical Technology and Research Centre, Alexandria University, Egypt. The rats were tested for normal health status and kept for 2 weeks for laboratory environment acclimatization. The rats were allowed free access to normal rat's food and tap water and were kept under conventional conditions of temperature, humidity, and light/dark cycle.

\section{Experimental design}

The rats were divided into seven groups (Fig. 2), $n=10$ for each, including, the control (C) group, normal rats where the rats were intraperitonially (IP) injected with saline (1 $\mathrm{ml} / \mathrm{kg}$ body weight (BW) three times per week for eight successive weeks; $\mathbf{T}$ group, the rats were IP injected with T (200 mg dissolved in $1 \mathrm{ml}$ saline/kg BW), three times per week for eight successive weeks (Morsy et al. 2015; Wallace et al. 2015); T-M group, the rats were injected with $\mathbf{T}$ as in $\mathbf{T}$ group; then at the beginning of the 9th week, the rats were orally administered with $1 \mathrm{~g}$ of $\mathrm{M} / \mathrm{kg} \mathrm{BW}$ (M was homogenized with $2 \mathrm{ml}$ distilled water) three times weekly for four successive weeks (Lucas et al. 2011); T-E group, the rats were injected with $\mathrm{T}$; then at the beginning of the 9th week, they were administered with $60 \mathrm{mg}$ of $\mathrm{E} / \mathrm{kg} \mathrm{BW}$ (E was suspended in $1 \mathrm{ml}$ distilled water) three times weekly for four weeks (Morsy et al. 2015); T-EM group, the rats were injected with $\mathrm{T}$; then at the beginning of the 9th week, they were administered with both $\mathrm{M}$ and $\mathrm{E}$, at the same day, respectively, three times weekly for four successive weeks; M-TM-M group, the rats were administered with $\mathrm{M}$ before (for 2 weeks), during, and after (for
2 weeks) $\mathrm{T}$ injection; and $\mathbf{M}$ group, $\mathbf{M}$ was administered three times per week for 12 weeks.

At the end of the experimental period (12 weeks), the rats were fasted overnight, weighted, anaesthetized by carbon dioxide, and sacrificed. Blood samples were collected from caudal vena cava, kept at room temperature for $15 \mathrm{~min}$, and then centrifuged at $3000 \mathrm{rpm}$ for $10 \mathrm{~min}$ to obtain serum, which stored at $-20^{\circ} \mathrm{C}$ until used. The livers were removed quickly; small parts of each were fixed in $10 \%$ formalin for microscopic examination. The remaining parts were washed with normal saline, divided into parts, and kept immediately at $-80^{\circ} \mathrm{C}$ until used.

\section{Biochemical assays}

\section{Markers of liver functions}

In serum, AST, ALT, GGT, bilirubin, albumin, and total protein (STP), beside hepatic albumin and total protein (LTP), were determined using kit (Malloy and Evelyn 1937; Gornall et al. 1949; Reitman and Frankel 1957; Szasz 1974; Tietz NaML 1987).

\section{Hepatic oxidative stress markers}

The liver homogenates were prepared by homogenizing the liver tissues in 10 volumes (w/v) of potassium phosphate buffer $(0.1 \mathrm{M}, \mathrm{pH} 7.5)$ using a glass-Teflon homogenizer (Shaban et al. 2014). The homogenates were centrifuged at $4000 \mathrm{rpm}$ for $20 \mathrm{~min}$ at $4{ }^{\circ} \mathrm{C}$, and the supernatants were kept at $-80^{\circ} \mathrm{C}$ until used for determination of the levels of MDA and GSH as well as the activities of SOD, GST, GPx, and GR. The MDA levels were determined using kit and expressed as nmol/mg tissue protein (Ohkawa et al. 1979). Total GSH and GSH were determined using kit and expressed as $\mathrm{mg} / \mathrm{mg}$ tissue protein (Sedlak and Lindsay 1968). Then, the GSSG levels were calculated from the equation: (GSSG $=$ Total GSH - reduced GSH). The redox status was demonstrated as GSH/GSSG ratio. The activities of GSR were determined using kit and expressed as nmol of NADPH consumed/mg tissue protein/min (Carlberg and Mannervik 1985). The SOD activities were determined using kit and expressed as U/mg tissue protein (Michiels et al. 1994). Total GST activities were measured using kit and expressed as nmol 1-chlor 2,4-dinitrobenzene (CDNB) conjugation/min/mg tissue protein (Habig et al. 1974). Total GPx activities were determined using kit and expressed as $\mu \mathrm{mol}$ NADPH consumed $/ \mathrm{min} / \mathrm{mg}$ tissue protein (Paglia and Valentine 1967). 
Fig. 2 An illustration of the experimental design. All animals received the normal diet throughout the whole experimental period

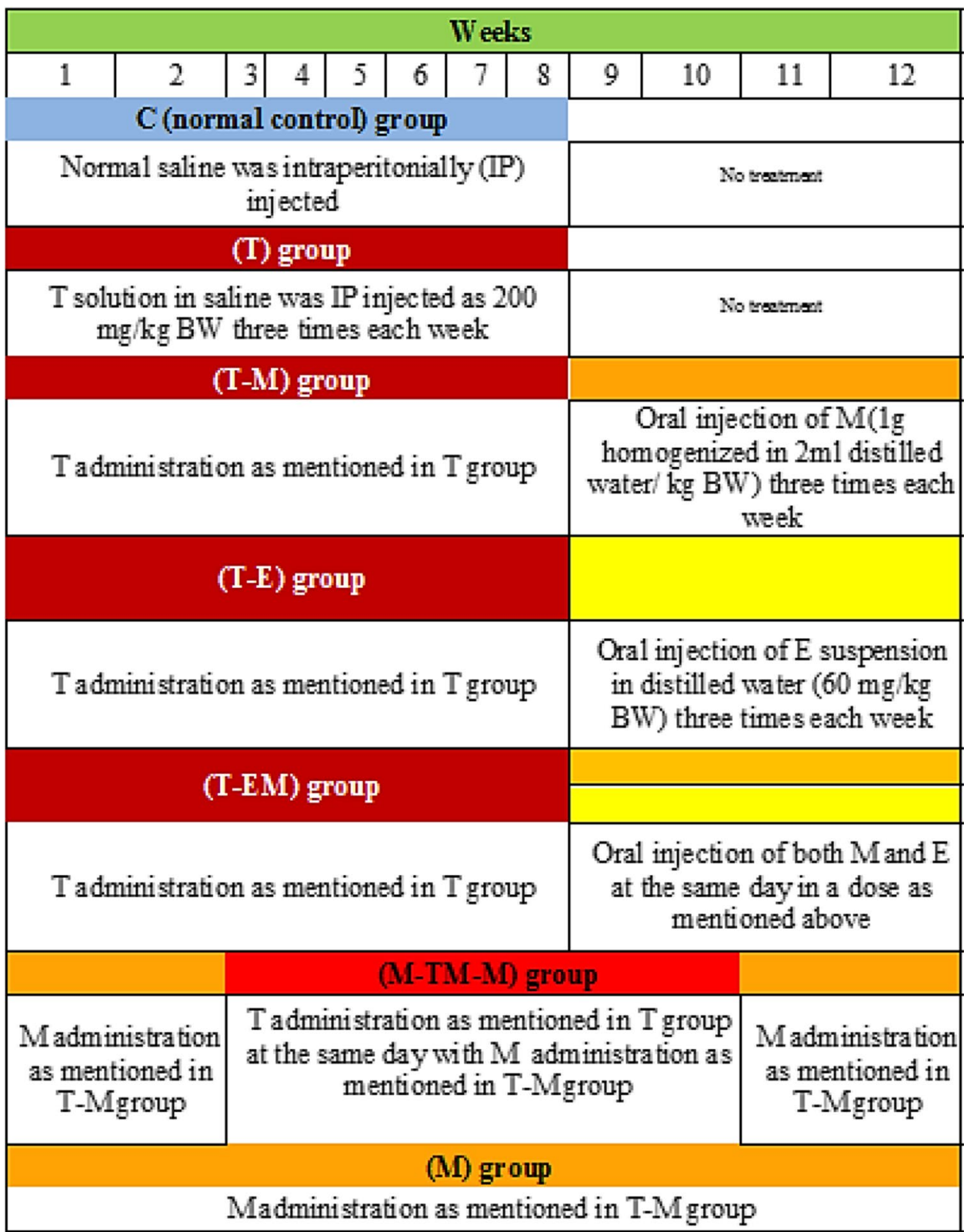

\section{The inflammatory and fibrotic markers}

\section{TNF- $a$ and PDGF-BB}

Serum levels of TNF- $\alpha$ and PDGF-BB of the different studied groups were determined as $\mathrm{pg} / \mathrm{mg}$ tissue protein, according to instructions of ELISA kits.

\section{TGF- $\beta 1$ expression assay}

Hepatic RNA of each rat was isolated according to the instructions of the kit. The purity of extracted RNA samples was tested by absorbance of RNA samples at 260 and at $280 \mathrm{~nm}$ ratio (A260/A280). RNA concentration was measured using spectrophotometer (BioDrop $\mu$ Lite, Australia), while its quality was confirmed by gel electrophoresis on $2 \%$ agarose gel which was stained with ethidium bromide. In the isolated RNA samples, TGF- $\beta 1$ expression levels were determined through quantitative reverse transcriptase PCR technique using SYBR green PCR master mix one-step kit. Briefly, in a $20 \mu \mathrm{l}$ reaction volume, $4 \mu \mathrm{l}$ of the template (RNA sample) was added to $10 \mu \mathrm{l}$ of $2 \times$ SYBR mix, $0.8 \mu \mathrm{l}$ of each $10 \mu \mathrm{M}$ forward and reverse primers, $0.4 \mu \mathrm{l}$ RNase inhibitor, $0.2 \mu 1$ reverse transcriptase, and $3.8 \mu$ RNase-free water. The reactions included one cycle 10-min reverse transcription at $45^{\circ} \mathrm{C}$, one cycle 2 min of polymerase activation 
at $95{ }^{\circ} \mathrm{C}$, and 40 cycles of $5 \mathrm{~s}$ denaturation at $95{ }^{\circ} \mathrm{C}, 10 \mathrm{~s}$ annealing at $60{ }^{\circ} \mathrm{C}$ and $72{ }^{\circ} \mathrm{C}$ extension. The expression level all studied groups were calculated from the PCR cycle number where the increased fluorescence curve passes across a threshold cycle (CT). The relative expression of TGF- $\beta 1$ gene was obtained using comparative CT $(\Delta \Delta \mathrm{CT})$ method, and GAPDH gene was used as internal control. $\Delta \mathrm{CT}$ and $\Delta \Delta \mathrm{CT}$ were calculated by following equations: $\Delta \mathrm{CT}=\mathrm{CT}_{(\mathrm{TGF}-\beta 1)}-\mathrm{CT}_{(\mathrm{GAPDH})}$ and $\Delta \Delta \mathrm{CT}=\Delta \mathrm{CT}$ (Sample) $-\Delta \mathrm{CT}$ (Control) $_{\text {The expression fold changes were calculated }}$ from this formula: Expression fold change $=2^{-\Delta \Delta \mathrm{CT}}$ (Livak and Schmittgen 2001). The following primers were used (Table 1): $T G F-\beta 1$ (GI: 57341) forward primer (5'-TGG CGTTACCTTGGTAACC-3'), reverse primer (5'-GGTGTT GAGCCCTTTCCAG-3'), GAPDH (GI: 10190788) forward primer (5'-AGCCCAGAACATCATCCCTG-3'), reverse primer (5'-CACCACCTTCTTGATGTCATC -3') (Wickert et al. 2002).

\section{Drug combination index $(\mathrm{Cl})$ analysis}

The drug and food combination may offer greater (synergistic), lesser (anti-synergistic), or no new (additive) outcome compared to the single agent. This result can be investigated by calculating the $\mathrm{CI}$ value (the predictable value divided by the observed value for T-EM). The effect of the co-administration (EM) on predictable values of major parameters was determined as [(observed value for $\mathrm{T}-\mathrm{M}) /(\mathrm{T}$ value $)] \times$ [(observed value for T-E)/(T value)] $\times(\mathrm{T}$ value $)[34]$. From the obtained CI values, the effect can be evaluated as synergism $(\mathrm{CI}<1)$, anti-synergism $(\mathrm{CI}>1)$, or additive (CI $=1$ ) (Zhou et al. 2007; Habashy et al. 2018; Shaban et al. 2020, 2021a).

\section{Hepatic microscopic examination}

The liver samples were embedded in paraffin, sectioned at 5 $\mu \mathrm{m}$ thickness, and stained with hematoxylin and eosin (H \& E) for microscopic examination (Suzuki and Suzuki 1998).

Table 1 The primers in qRT-PCR analysis

\begin{tabular}{lll}
\hline Gene & Primer name & Sequence $\left(5^{\prime}-3^{\prime}\right)$ \\
\hline$T G F-\beta 1$ (GI: 57341) & Forward & TGGCGTTACCTTGGT \\
& & AACC \\
& Reverse & GGTGTTGAGCCCTTT \\
& & CCAG \\
GAPDH (GI: 10190788) & Forward & AGCCCAGAACATCAT \\
& & CCCTG \\
& Reverse & CACCACCTTCTTGAT \\
& & GTCATC \\
\hline
\end{tabular}

\section{Statistical analysis}

All data were given as means \pm SD. Comparisons between the means of studied groups were performed by Tukey's test (ANOVA) using the statistical software SPSS 16.0 V (SPSS, Inc., Chicago, IL, USA), and the differences were considered significant at $(P \leq 0.05)$.

\section{Results}

\section{Total phenolics and total flavonoids and HPLC analysis}

The results showed that $1 \mathrm{~g}$ of $\mathrm{M}$ contains $419 \pm 1.04 \mu \mathrm{g}$ total phenolics as gallic acid equivalent and $6.8 \pm 0.05 \mu \mathrm{g}$ total flavonoids as quercetin equivalent. Also, the results in Table 2 show that M contains chlorogenic, caffeic, 2,5-dihydroxy benzoic, 3,5-dicaffeoylquinic, 4,5-dicaffeoylquinic, tannic acid, cinnamic acid, catechin, phloridzin, and quercetin with different concentrations.

\section{Minerals}

The results revealed that $\mathrm{M}$ contains different concentrations from potassium, calcium, magnesium, sodium, iron, copper, zinc, and manganese (Table 2).

\section{Total antioxidant capacity}

The current results showed that the total antioxidant capacity of $1 \mathrm{~g}$ of $\mathrm{M}$ was $117.2 \pm 1.16 \mathrm{as} \mu \mathrm{g}$ ascorbic acid equivalent.

\section{Different treatments improved liver dysfunctions induced by $T$}

The results in Table 3 show that $\mathrm{T}$ injection caused significant $(P<0.001)$ elevations in the levels of ALT, AST, GGT, and bilirubin as compared to the $\mathrm{C}$ group, whereas LTP, STP, and albumin levels were reduced. In contrast, ALT, AST, GGT, and bilirubin of rats treated by $\mathbf{M}, \mathbf{E}$, and ME after T injection or M-TM-M became lower than the T group, while LTP, STP, and albumin levels were greater. In comparison with $\mathrm{C}$ group, $\mathrm{M}$ group results showed nonsignificant changes. Generally, ME treatment gave lower effect than the treatment with $\mathrm{M}$ and $\mathrm{E}$ separately, as well as M-TM-M treatment showed better effect than M treatment. 


\section{Different treatments reduced $0 S$ induced by $T$}

The results in Figs. 3 and 4 show that $\mathrm{T}$ injection caused significant $(P<0.001)$ elevations in the levels of MDA and GSSG and the activities of GST and GSR as compared with the $\mathrm{C}$ group, but the antioxidants (GSH, GPx and SOD) and redox status level were significantly $(P<0.001)$ declined. However, M, E, or ME treatments after T injection, as well as M-TM-M, significantly reduced the levels of MDA, GSSG, GST, and GSR when compared with the T group, although GSH levels, GPx, and SOD activities, and redox status levels were increased. In addition, results after only $\mathrm{M}$ administration ( $\mathrm{M}$ group) showed non-significant changes in these parameters as compared with $\mathrm{C}$ group. Of note, ME treatment gives lower effect than the treatment with $\mathrm{M}$ and $\mathrm{E}$ separately (anti-synergistic effect) (Table 4).

Table 2 Mango pulp phenolics, flavonoids, and minerals contents

\begin{tabular}{lllc}
\hline Phenolics/flavonoids & $\begin{array}{l}\text { Concentra- } \\
\text { tion }(\mu \mathrm{g} / 100 \\
\mathrm{g})\end{array}$ & Minerals & $\begin{array}{l}\text { Concentration } \\
(\mathrm{mg} / 100 \mathrm{~g})\end{array}$ \\
\hline Catechin & 278.4 & $\mathrm{~K}$ & 142.4 \\
Quercetin & 266.5 & $\mathrm{Ca}$ & 20.8 \\
3,5-Dicaffeoyl quinic acid & 100.8 & $\mathrm{Mg}$ & 3.2 \\
Cinnamic acid & 80.0 & $\mathrm{Na}$ & 2.4 \\
Chlorogenic acid & 73.7 & $\mathrm{Fe}$ & 0.8 \\
2,5-Dihydroxy benzoic acid & 53.6 & $\mathrm{Cu}$ & 0.2 \\
Phloridzin & 26.8 & $\mathrm{Zn}$ & 0.2 \\
4,5-Dicaffeoyl quinic acid & 24.8 & $\mathrm{Mn}$ & 0.1 \\
Caffeic acid & 13.6 & & \\
Tannic acid & 7.2 & & \\
\hline
\end{tabular}

\section{Different studied treatments reduced liver inflammation and fibrosis induced by $T$}

The results in Fig. 5 reveal that $\mathrm{T}$ administration caused significant $(P<0.001)$ elevations in the levels of TNF- $\alpha$ and PDGF-BB beside significant $(P<0.05)$ up-regulation of the TGF- $\beta 1$ gene expression level as compared with the C group. However, treatment with M, E, ME, or M-TM-M after $\mathrm{T}$ injection significantly decreased these markers as compared to the $\mathrm{T}$ group. Moreover, the $\mathrm{M}$ group showed non-significant changes in results of these parameters as compared with the results of the $\mathrm{C}$ group. Noteworthy, ME treatment has a lower effect than the treatment with $\mathrm{M}$ and E separately as shown in Table 4.

\section{Different studied treatments improved liver histopathology induced by $T$}

Histopathological examinations in (Fig. 6a and b) demonstrate that $\mathrm{C}$-group showed normal central vein surrounded by normal hepatocytes which arranged in cords and separated by blood sinusoids; T-group showed excessive periportal and inter lobular fibrosis (black star), loss general architecture of hepatic lobules, mononuclear cell infiltration (black arrowhead), binucleated hepatocytes (black arrow), and pyknotic nuclei undergoing apoptosis (white arrow). Moreover, T-M group showed no fibrosis but a small number of pyknotic nuclei and a little periportal degeneration of hepatocytes with mononuclear cells infiltration; T-E group showed a small number pyknotic nuclei (white arrow) and mononuclear cells infiltration (black arrow) (Fig. 6c and d). T-EM group showed little periportal fibrosis (black arrow), pyknotic nuclei (white arrowhead), blood vessel congestion

Table 3 Effect of different treatments on liver functions

\begin{tabular}{|c|c|c|c|c|c|c|c|}
\hline \multicolumn{6}{|l|}{ Studied groups } & \multirow[b]{2}{*}{ M-TM-M } & \multirow[b]{2}{*}{ M } \\
\hline Parameters & $\mathrm{C}$ & $\mathrm{T}$ & T-M & T-E & EM & & \\
\hline \multicolumn{8}{|l|}{ In serum: } \\
\hline ALT (U/L) & $74.8 \pm 3.2$ & $128.5^{\mathrm{a}} \pm 1.9$ & $102.2^{\mathrm{a}, \mathrm{b}} \pm 2.7$ & $77.8^{\mathrm{b}, \mathrm{c}} \pm 1.0$ & $99^{\mathrm{a}, \mathrm{b}} \pm 2.0$ & $81.0^{\mathrm{a}, \mathrm{b}, \mathrm{c}} \pm 3.7$ & $76.1^{\mathrm{b}, \mathrm{c}} \pm 0.5$ \\
\hline AST (U/L) & $107.9 \pm 2.1$ & $191.3^{\mathrm{a}} \pm 3.8$ & $141^{\mathrm{a}, \mathrm{b}} \pm 0.9$ & $110.8^{\mathrm{b}, \mathrm{c}} \pm 0.3$ & $145.9^{\mathrm{a}, \mathrm{b}, \mathrm{c}, \mathrm{d}} \pm 1.9$ & $117.5^{\mathrm{a}, \mathrm{b}, \mathrm{c}} \pm 3.7$ & $110.6^{b, c} \pm 2.7$ \\
\hline GGT (U/L) & $3.0 \pm 0.2$ & $14.7^{\mathrm{a}} \pm 0.5$ & $5.5^{\mathrm{a}, \mathrm{b}} \pm 0.2$ & $4.1^{\mathrm{a}, \mathrm{b}, \mathrm{c}} \pm 0.2$ & $8.5^{\mathrm{a}, \mathrm{b}, \mathrm{c}, \mathrm{d}} \pm 0.2$ & $4^{\mathrm{a}, \mathrm{b}, \mathrm{c}} \pm 0.2$ & $3.3^{\mathrm{b}, \mathrm{c}} \pm 0.1$ \\
\hline T.bil (mg/dl) & $0.3 \pm 0.0$ & $0.9^{\mathrm{a}} \pm 0.0$ & $0.5^{\mathrm{a}, \mathrm{b}} \pm 0.0$ & $0.33^{\mathrm{a}, \mathrm{b}, \mathrm{c}} \pm 0.02$ & $0.48^{\mathrm{a}, \mathrm{b}, \mathrm{d}} \pm 0.01$ & $0.4^{\mathrm{a}, \mathrm{b}, \mathrm{c}} \pm 0.02$ & $0.25^{\mathrm{b}, \mathrm{c}, \mathrm{d}} \pm 0.03$ \\
\hline $\mathrm{Alb}(\mathrm{g} / \mathrm{dl})$ & $3.9 \pm 0.2$ & $2.5^{\mathrm{a}} \pm 0.2$ & $2.8^{\mathrm{a}} \pm 0.2$ & $3.4^{\mathrm{b}, \mathrm{c}} \pm 0.3$ & $3.6^{\mathrm{b}, \mathrm{c}} \pm 0.1$ & $3.4^{\mathrm{a}, \mathrm{b}, \mathrm{c}} \pm 0.3$ & $3.6^{\mathrm{b}, \mathrm{c}} \pm 0.1$ \\
\hline T.P $(\mathrm{g} / \mathrm{dl})$ & $5.7 \pm 0.3$ & $3.5^{\mathrm{a}} \pm 0.2$ & $4.1^{\mathrm{a}} \pm 0.5$ & $5^{\mathrm{a}, \mathrm{b}, \mathrm{c}} \pm 0.1$ & $3.9^{\mathrm{a}, \mathrm{d}} \pm 0.4$ & $4.9^{\mathrm{a}, \mathrm{b}, \mathrm{c}} \pm 0.3$ & $5.5^{\mathrm{b}, \mathrm{c}, \mathrm{d}} \pm 0.1$ \\
\hline \multicolumn{8}{|l|}{ In liver: } \\
\hline Alb (g/g. liver) & $6.2 \pm 0.3$ & $3.3^{\mathrm{a}} \pm 0.2$ & $4.8^{\mathrm{a}, \mathrm{b}} \pm 0.3$ & $4.8^{\mathrm{a}, \mathrm{b}, \mathrm{c}} \pm 0.1$ & $3.8^{\mathrm{a}, \mathrm{b}, \mathrm{c}, \mathrm{d}} \pm 0.3$ & $271.7^{\mathrm{a}, \mathrm{b}, \mathrm{c}} \pm 17.1$ & $297.2^{\mathrm{b}, \mathrm{c}, \mathrm{d}} \pm 4.0$ \\
\hline T.P (g/g. liver) & $7.7 \pm 0.1$ & $4.1^{\mathrm{a}} \pm 0.1$ & $6.6^{\mathrm{a}, \mathrm{b}} \pm 0.5$ & $6.3^{\mathrm{a}, \mathrm{b}} \pm 0.3$ & $5.4^{\mathrm{a}, \mathrm{b}, \mathrm{c}, \mathrm{d}} \pm 0.2$ & $341.7^{\mathrm{a}, \mathrm{b}} \pm 14.9$ & $385.2^{\mathrm{b}, \mathrm{c}, \mathrm{d}} \pm 14.9$ \\
\hline
\end{tabular}

$C$ control rats; $T$ rats were injected with thioacetamide; $T-M$ rats were treated by mango pulp (M) after T injection; $T-E$ rats were treated by eprosartan (E) after T injection; T-EM rats were treated by both $\mathrm{E}$ and $\mathrm{M} ; M-T M-M$ group rats were treated by $\mathrm{M}$ before, during, and after T; and $M$ group rats were treated by $\mathrm{M}$ only. ALT (alanine transaminase), AST (aspartate transaminase), GGT (gamma-glutamyl transpeptidase), T.bil (total bilirubin), Alb (albumin), and T.P (total protein). Since a significant $(p<0.05)$ vs $\mathrm{C}$ group; b significant $(p<0.05)$ vs T group and $\mathrm{c}$ significant $(p<0.05)$ vs T-M group, d significant $(p<0.05)$ vs T-E group, $n=10$ per group, and the data are being presented as the mean \pm SD 


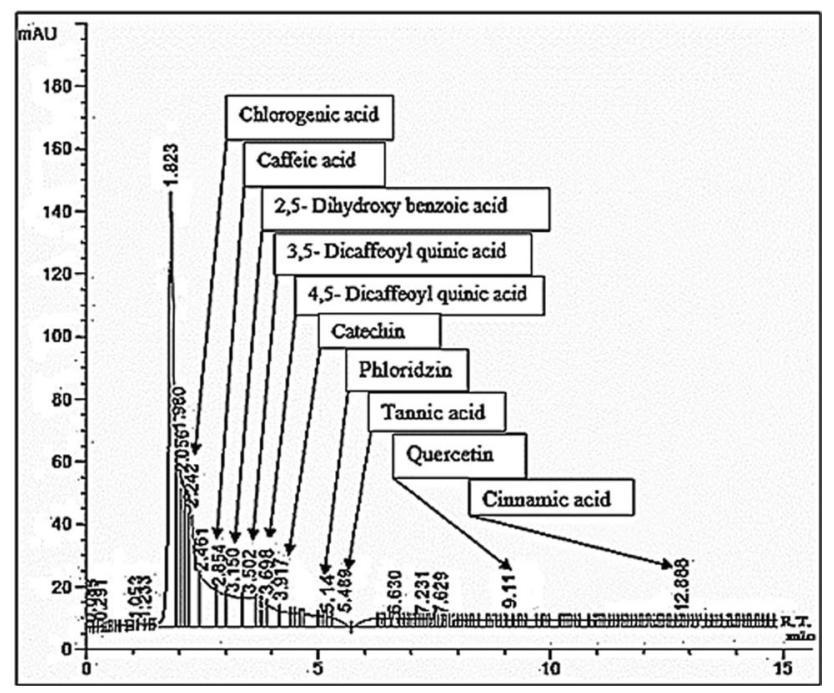

Fig. 3 HPLC analysis of phenolics and flavonoids in M pulp

(black star), binucleated hepatocytes (white arrow), and mononuclear cell infiltration (black arrowhead) (Fig. 6e). M-TM-M group showed pyknotic nuclei (white arrow), blood vessel congestion (black star), and few centrilobular degeneration of hepatocytes (black arrow) and mononuclear cells infiltration (black arrowhead). Additionally, M-group showed only blood vessel congestion (black star) and numerous pyknotic nuclei (black arrow) (Fig. $6 \mathrm{f}$ and g).

\section{Discussion}

Epidemiological studies have revealed that phenolics (including flavonoids)-rich diets decrease mortality caused by degenerative diseases resulting by the OS (Pandey and Rizvi 2009). Our results showed that M contains high content of total phenolics and total flavonoids where their analysis showed the presence of chlorogenic, caffeic, 2,5-dihydroxy benzoic, 3,5-dicaffeoylquinic, 4,5-dicaffeoylquinic, tannic and cinnamic acids, and catechin, phloridzin , and quercetin. Additionally, M contains mangiferin, kaempferol, and gallotannins (Masibo and He 2009). Furthermore, M is a rich source of vitamins A and C. All these compounds have antioxidant activity (Lauricella et al. 2017), and this confirmed by our results which showed that $\mathrm{M}$ has high total antioxidant capacity. So, in this current study, the protective and therapeutic role of $\mathrm{M}$ and the drug E, separately, was evaluated against rat hepatotoxicity caused by $\mathrm{T}$. Also, the therapeutic role of $\mathrm{M}$ and $\mathrm{E}$ together against hepatotoxicity was evaluated to determine the synergistic effect.

The current histopathological results revealed that $\mathrm{T}$ administration induced hepatotoxicity resulting in liver damage and this was confirmed by the disturbance of liver functions since the liver damage led to the leakage of its enzymes into the blood circulation. So, AST, ALT, GGT, and bilirubin levels in serum were elevated as compared to the C group, while STP, albumin, and LTP were reduced. Furthermore, our results showed that $\mathrm{T}$ administration caused elevations in MDA and GSSG levels beside GST and GSR activities as compared with the $\mathrm{C}$ group, but reduced GSH level and redox status (GSH/GSSG), and GPx and SOD activities. This indicates that $\mathrm{T}$ induced hepatotoxicity through the induction of OS. The increase in MDA content is an important index of lipid peroxidation, and this may be due to an enhanced generation of free radicals, which accelerated peroxidation of native membrane lipids especially polyunsaturated fatty acids (Shaban et al. 2003, 2017). Peroxidation of membrane lipids leads to loss of cell integrity, increasing in membrane permeability and alteration of $\mathrm{Ca}^{+2}$ homeostasis and change in the inner membrane potential causing cell damage (Shaban et al. 2003). The mechanism of hepatotoxicity by $\mathrm{T}$ may be due to the toxic effect of $\mathrm{T}$ and its reactive metabolites (T-S-oxide and T-S,S-dioxide radicals). These radicals accelerate the peroxidation of membrane lipids leading to the damage of the cells and their intracellular organelles (Friedman 1999; Saed et al. 2017; Shaban et al. 2017). Otherwise, GSH acts as a cofactor to some enzymes including GPx as well as it acts as nucleophilic scavenger of several active compounds by chemical and enzymatic mechanisms. So, the reduction in GSH level after T administration may be due to increase its demand for lipid hydroperoxide metabolism by GPx. Also, the diminishing GSH level may be due to its interaction with any free radicals, including T-S-oxide and T-S, S-dioxide. GSR plays an important role in cellular protection against OS by reducing GSSG accumulation of and thus maintaining the redox state. So, the increase in GSR activity after $\mathrm{T}$ administration possibly reflects an adaptation to oxidative circumstances (Shaban et al. 2003). GST is a versatile system involved in xenobiotics detoxification. It protects the cell against electrophilic radicals through catalyzing the conjugation of GSH with radicals via thioether linkages forming glutathione-S-conjugates leading to increase GST activity (Sanz et al. 2002). Furthermore, T, T-S-oxide and T-S,S-dioxide may increase GST gene expression through specific receptors, which are up-regulated by inflammatory and fibrotic agents including TNF $\alpha$ and TGF- $\beta$ (Higgins and Hayes 2011). Conversely, the decrease in SOD and GPx activities may be related to their inhibition by $\mathrm{T}$ and its metabolites through direct interaction with the enzyme molecules or modification of the post-transcriptional and post-translational steps in enzyme synthesis (Hayakawa and Kuzuya 1990). Also, SOD inhibition may be associated with the oxidation of its cysteine residues (Shaban et al. 2014). Additionally, GSH depletion leads to the reduction of GPx activity (Chen et al. 2015). Otherwise, TNF- $\alpha$ is a major 
Fig. 4 Effect of different studied treatments on the oxidative stress markers, where C: control rats; T: rats were injected with thioacetamide; T-M: rats were treated by mango pulp (M) after $\mathrm{T}$ injection; T-E: rats were treated by eprosartan (E) after $\mathrm{T}$ injection; T-EM: rats were treated by both $\mathrm{E}$ and $\mathrm{M}$ after $\mathrm{T}$ injection; M-TM-M group: rats were treated by $\mathrm{M}$ before, during, and after $\mathrm{T}$; and $\mathrm{M}$ group: rats were treated by $\mathrm{M}$ only. Since a significant $(p<$ $0.05)$ vs $\mathrm{C}$ group; b significant $(p<0.05)$ vs T group and c significant $(p<0.05)$ vs T-M group, d significant $(p<0.05)$ vs T-E group, $n=10$ per group, and the data are being presented as the mean \pm SD. GSH and GSSG levels are being expressed as $\mathrm{mg} / \mathrm{mg}$ protein and MDA as nmol/mg protein; GPX-specific activities are being expressed as $\mu \mathrm{mol}$ NADPH/ $\mathrm{min} / \mathrm{mg}$ protein, SOD as $\mathrm{U} / \mathrm{mg}$ protein, GST as $\mu \mathrm{mol}$ CDNB/ $\mathrm{min} / \mathrm{mg}$ protein, and GSR as $\mathrm{nmol} \mathrm{NADPH} / \mathrm{min} / \mathrm{mg}$ protein
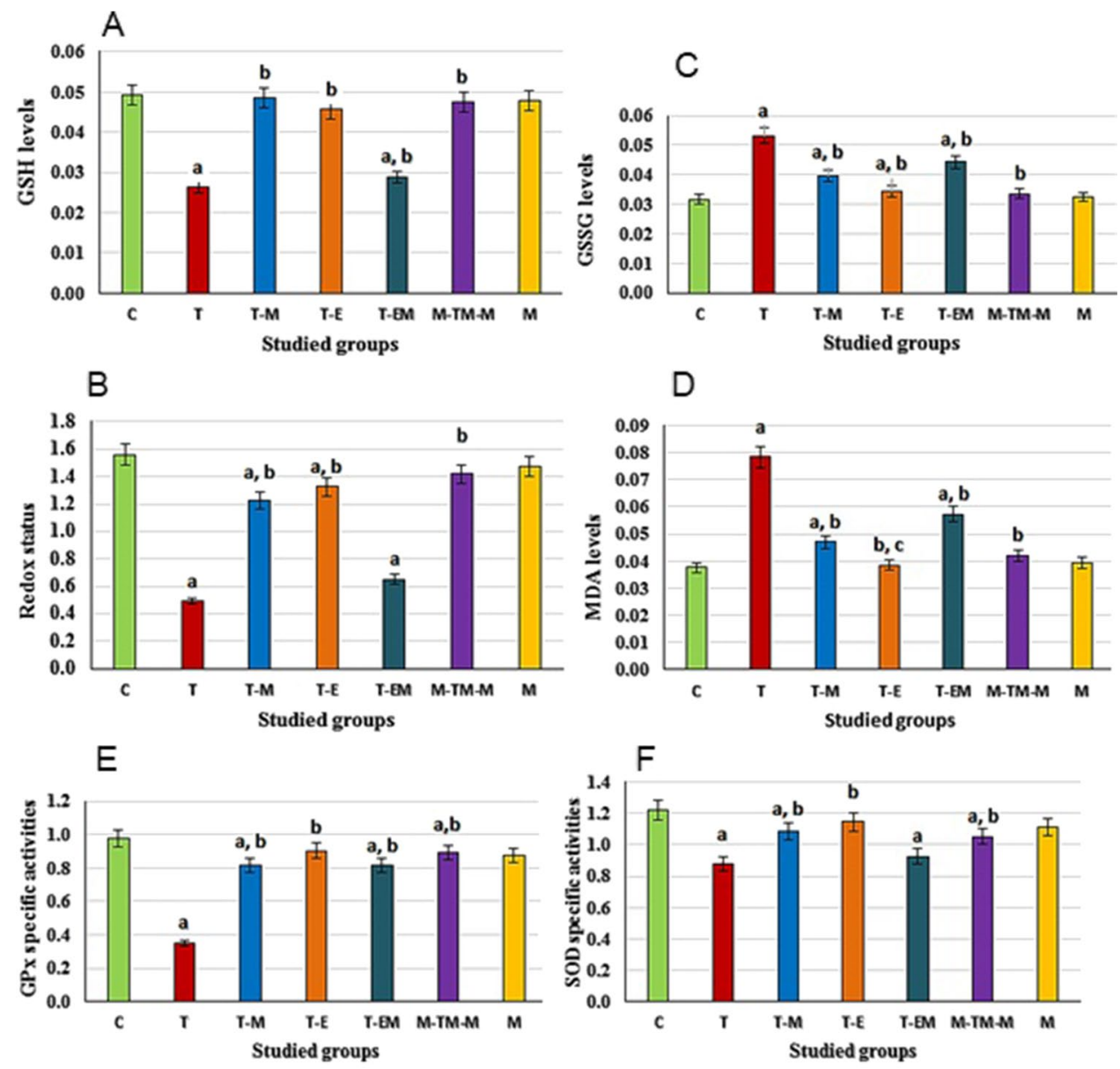

G

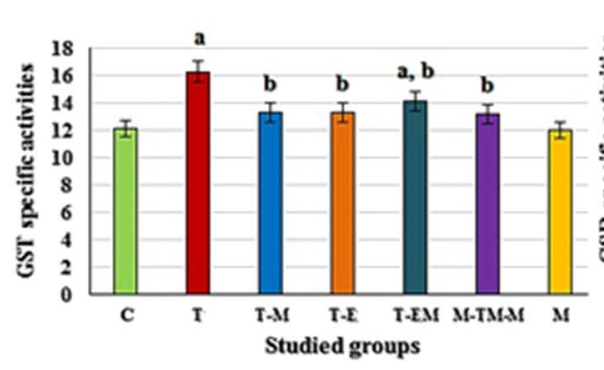

pro-inflammatory cytokine involved in early inflammatory events. It triggers a series of various inflammatory molecules, including other cytokines, chemotactic cytokines, and chemokines, such as interleukin 8. Otherwise, PDGF-BB is one of numerous growth factors that regulate cell growth and division. PDGF-BB plays a significant role in blood vessel formation and proliferation of mesenchymal cells such as fibroblasts. Our results showed that $\mathrm{T}$ administration caused elevations in 15 levels beside up-regulation of the TGF- $\beta 1$ gene expression level when compared with the $\mathrm{C}$ group. This indicates that $\mathrm{T}$ induced liver inflammation and fibrosis, and this may be linked to the increase in lipid peroxidation. The lipid peroxidation induces over expression of cytokines and increases the synthesis of collagen which activates hepatic stellate cells (HSCs) (Rejitha et al. 2012; Ulla et al. 2017). The activated HSCs and immune cells induce production and secretion of TGF- $\beta 1$ and PDGF-BB where the overproduction of TGF- $\beta 1$ is a major cause of tissue fibrosis (Habtemariam 1997; Park et al. 2016).

In contrast, treatment of rat hepatotoxicity with $\mathrm{M}$ [(before, during and after) or after $\mathrm{T}$ administration] or $\mathrm{E}$ or ME improved liver architecture where the microscopic examination showed that there were no fibrosis. but there were small numbers of pyknotic nuclei undergoing apoptosis. Also, we noticed that the histopathology and biochemical results are in harmony with each other. Since all these 
Table 4 The combination index (CI)* values for the mango pulp (M) and eprosartan drug (E) co-administration on major tested parameters

\begin{tabular}{lll}
\hline Parameters & CI* $^{*}$ & Effect \\
\hline GSH & $2.9 \pm 0.1$ & Anti-synergistic \\
GSSG & $1.7 \pm 0.0$ & Anti-synergistic \\
GSH/GSSG & $5.1 \pm 0.3$ & Anti-synergistic \\
GPx & $2.6 \pm 0.2$ & Anti-synergistic \\
SOD & $1.5 \pm 0.1$ & Anti-synergistic \\
GST & $1.3 \pm 0.0$ & Anti-synergistic \\
GSR & $2.9 \pm 0.2$ & Anti-synergistic \\
MDA & $2.5 \pm 0.2$ & Anti-synergistic \\
PDGF-BB & $1.9 \pm 0.1$ & Anti-synergistic \\
TNF- $\alpha$ & $2.4 \pm 0.4$ & Anti-synergistic \\
TGF- $\beta 1$ & $2.3 \pm 0.2$ & Anti-synergistic \\
\hline
\end{tabular}

GSH (glutathione), GSSG (reduced glutathione), GPx (glutathione peroxidase), SOD (superoxide dismutase), GST (glutathione-S-transferase), GSR (glutathione reductase), MDA (malonedialdehyde), TNF$\alpha$ (tumor necrosis factor- $\alpha$ ), and PDGF-BB (platelet-derived growth factor-BB), and TGF- $\beta 1$ (transforming growth factor-beta1 and the data are being presented as the mean $\pm \mathrm{SD}$

* CI values determine the type of impact between $\mathrm{E}$ and $\mathrm{M}$. the effect can be evaluated as synergism $(\mathrm{CI}<1)$, anti-synergism $(\mathrm{CI}>1)$, or additive $(C I=1)$ (Zhou et al. 2007; Habashy et al. 2018; Shaban et al. 2020, 2021a, 2022)

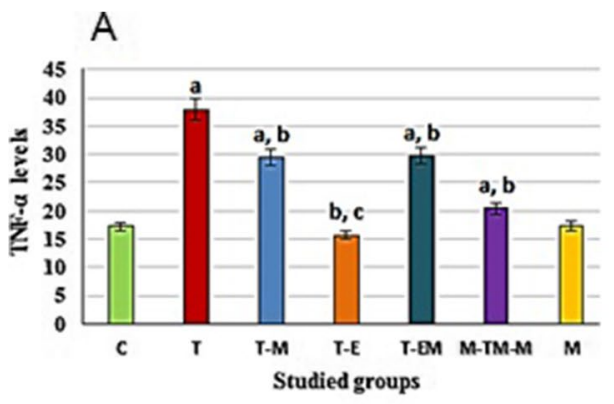

treatments improved the liver functions as the levels of AST, ALT, and GGT and bilirubin became lower than the T group, while TP and albumin in serum and hepatic TP became greater than the T group. Also, these treatments decreased OS, lipid peroxidation, liver inflammation, liver fibrosis, and liver injuries induced by $\mathrm{T}$. The levels of MDA and GSSG and the activities of GST and GR were decreased, but GSH level and the activities of SOD and GPx were increased indicating that $\mathrm{M}$ and $\mathrm{E}$ have antioxidant activity. Furthermore, these treatments caused reduction in the levels of TNF- $\alpha$, PDGF-BB, and TGF- $\beta 1$ expression which became lower than the $\mathrm{T}$ group and this signifying that $\mathrm{M}$ and $\mathrm{E}$ have antiinflammatory and anti-fibrotic activities. Otherwise, the present results revealed that treatment with $\mathrm{M}$ before, during, and after $\mathrm{T}$ administration (i.e., protective role) gave better results than treatment with $\mathrm{M}$ after the administration of $\mathrm{T}$ (i.e., therapeutic role). The mechanism of the protective and therapeutic effects of $\mathrm{M}$ may be related to the antioxidant activity of its contents, including phenolics and flavonoids and their gradients, carotenoids, vitamins, and some minerals. The antioxidant activities of phenolic and flavonoid compounds may be due to their ability to scavenge the ROS and their capability to up-regulate non-enzymatic and enzymatic antioxidants (López et al. 2007; Mehra et al. 2013; Abdel-Rahman et al. 2015; Shaban et al. 2016b; Ulla et al.

\section{B}

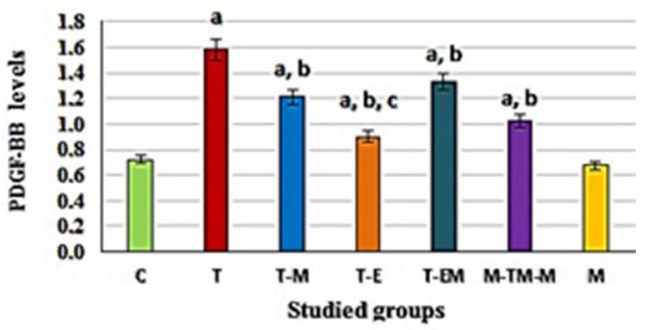

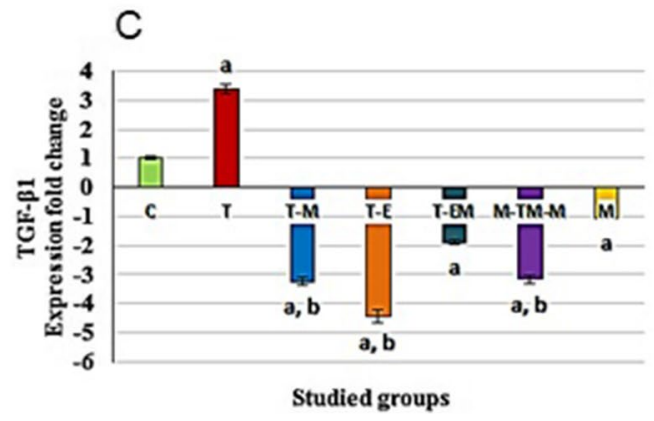

Fig. 5 Effect of different studied treatments on hepatic inflammatory and fibrotic markers, where $\mathrm{C}$ : control rats; $\mathrm{T}$ : rats were injected with thioacetamide; T-M: rats were treated by mango pulp (M) after $\mathrm{T}$ injection; T-E: rats were treated by eprosartan (E) after T injection; T-EM: rats were treated by both $\mathrm{E}$ and $\mathrm{M}$ after $\mathrm{T}$ injection; $\mathrm{M}-\mathrm{TM}-$ $M$ group: rats were treated by $\mathrm{M}$ before, during, and after $\mathrm{T}$; and $\mathrm{M}$ group: rats were treated by $M$ only. TNF- $\alpha$ (tumor necrosis factor- $\alpha$ ) and PDGF-BB (platelet-derived growth factor-BB) levels are being expressed as $\mathrm{pg} / \mathrm{mg}$ protein, and TGF- $\beta 1$ (transforming growth factorbeta1) expressed as fold change using $G A P D H$ gene as housekeeping gene. Since a significant $(p<0.05)$ vs $\mathrm{C}$ group; b significant $(p<$ $0.05)$ vs T group and c significant $(p<0.05)$ vs T-M group, d significant $(p<0.05)$ vs T-E group, $n=10$ per group, and the data are being presented as the mean \pm SD 

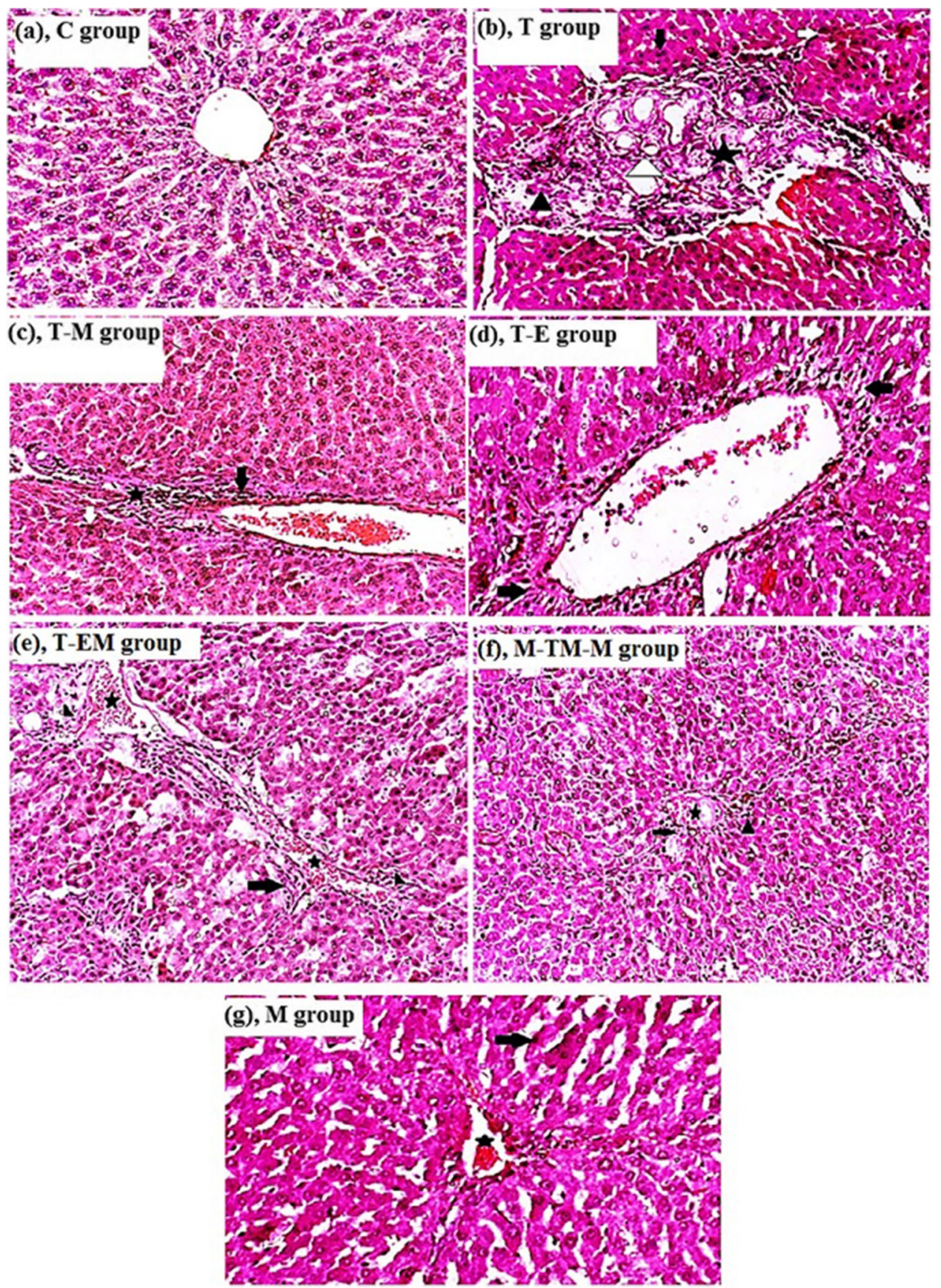

Fig. 6 Effect of different studied treatments on the microscopic examination of liver sections ( $\mathrm{H} \& \mathrm{E}$ staining; 20x), where (a) the normal control, $\mathbf{C}$ group, the liver sections showing normal central vein surrounded by normal hepatocytes which arranged in cords and separated by blood sinusoids); (b) T group, rats were injected with thioacetamide $(\mathrm{T})$ showing excessive periportal and inter lobular fibrosis (black star), loss of general architecture of hepatic lobules, mononuclear cell infiltration (black arrowhead), binucleated hepatocytes (black arrow), bile duct hyperplasia (white arrowhead) and pyknotic nuclei undergoing apoptosis (white arrow); (c) T-M group, rats were treated by mango pulp (M) after $\mathrm{T}$ injection showing a small number pyknotic nuclei undergoing apoptosis (white arrow) and a little periportal degeneration of hepatocytes (black arrow) with mononuclear cells infiltration and myofibroblasts (black star); (d) T-E group, rats were treated by eprosartan (E) showing no fibrosis but there were small number of pyknotic nuclei undergoing apoptosis (white arrow) and pericentral hepatocyte degeneration (black arrow); (e) T-EM group, rats were simultaneously treated by both $\mathrm{E}$ and $\mathrm{M}$ after $\mathrm{T}$ injection showing periportal fibrosis (black arrow), pyknotic nuclei (white arrowhead), blood vessel congestion (black star), binucleated hepatocytes (white arrow) and mononuclear cell infiltration (black arrowhead); (f) M-TM-M group, rats were treated by $\mathbf{M}$ before, during, and after $\mathrm{T}$ injection showing pyknotic nuclei (white arrow), blood vessel congestion (black star), and few centrilobular degeneration of hepatocytes (black arrow) and mononuclear cells infiltration (black arrowhead); and (g) M group, rats were treated by $\mathbf{M}$ only showing only blood vessel congestion (black star), and numerous pyknotic nuclei (black arrow) 
2017). Additionally, carotenoids, vitamins as A and C, and some minerals as $\mathrm{Zn}$ and $\mathrm{Cu}$ play important roles as antioxidants. $\mathrm{Cu}$ is a principal component of SOD and has a vital role in the synthesis of antioxidant protein called ceruloplasmin (Shazia et al. 2012).

The anti-inflammatory and anti-fibrotic effects of $\mathrm{M}$ are probably due to the presence of phenolics, flavonoids, and their gradients. Phenolics and flavonoids, including quercetin, catechin, chlorogenic acid, and mangiferin, attenuate TNF- $\alpha$-induced expression of inflammatory genes and signaling pathways, suppress TGF- $\beta$-induced collagen production, and induce a apoptosis (Masibo and He 2009; Islam et al. 2014; Ooi et al. 2016; Shaban et al. 2016a; SantanaGálvez et al. 2017). In addition, the reduction of OS led the reduction of TNF- $\alpha$, PDGF-BB, and TGF- $\beta 1$ expression. It has been reported that the inhibitors of TGF- $\beta 1$ may be clinically useful as anti-fibrotic agents (Rejitha et al. 2012; Ulla et al. 2017).

On the other hand, our results showed the reduction in OS, lipid peroxidation, and liver damage in rats treated with $\mathrm{E}$ after $\mathrm{T}$ administration indicating that $\mathrm{E}$ has antioxidant power. These results reconcile with Labiós et al. (2008) who reported that $\mathrm{E}$ corrects the oxidative disturbances in hypertensive patients via the reduction of ROS and reactive nitrogen species and quenching the free radicals. Also, the anti-inflammatory and anti-fibrotic effects of E perhaps owed to its ability to control the increasing levels of Ang II, TGF- $\beta$, and collagen expressions. These results are in agreement with the results of the previous studies (Labiós et al. 2008; Masibo and He 2009). Unfortunately, treatment with $\mathrm{M}$ and $\mathrm{E}$ together after $\mathrm{T}$ administration gave the lower impact than the treatment with $\mathrm{M}$ or $\mathrm{E}$ in all markers of the OS, inflammation, fibrosis, and liver functions. The data showed that the $\mathrm{CI}$ values for the $\mathrm{M}$ and $\mathrm{E}$ co-administration on major tested parameters are greater than one. This points that there is anti-synergistic effect between $\mathrm{M}$ and $\mathrm{E}$, and this may be related to the effect of the different gradients of $\mathrm{M}$. These gradients may decrease the absorption of $\mathrm{E}$, or may decrease the binding of $\mathrm{E}$ with the blood protein (albumin), or may decrease the binding of $\mathrm{E}$ with its receptor. In addition, we suggest that some $\mathrm{M}$ gradients may bind with $\mathrm{E}$ forming inactive product. All these probabilities may decrease the bioavailability of each $\mathrm{E}$ and $\mathrm{M}$ as antioxidant, anti-inflammatory, and anti-fibrotic (Rodríguez-Fragoso and Reyes-Esparza 2013).

Otherwise, the administration of healthy rats with $\mathrm{M}$ for 12 weeks showed non-significant changes in histopathological results and the markers of the OS, inflammation, fibrosis, and liver functions when compared with the $\mathrm{C}$ group. These changes may be due to the accumulation of some polyphenolics and $\mathrm{Fe}$ and $\mathrm{Ca}$ ions in liver tissues, where the phenolics and flavonoids are metabolized by peroxidases in the presence of $\mathrm{Fe}$ and $\mathrm{Ca}$ ions forming free radicals (Shazia et al. 2012; Shaban et al. 2013). These observations are agreeing with previous studies (Shaban et al. 2014, 2017).

\section{Conclusion}

$\mathrm{M}$ and $\mathrm{E}$ revealed their therapeutic effect against hepatotoxicity induced by $\mathrm{T}$ by diminishing the oxidative stress, inflammation, and fibrosis. Also, $\mathrm{M}$ showed its protective role against hepatotoxicity where the treatment with $\mathrm{M}$ before, during, and after T administration (group M-TMTM) gave a better effect than its treatment after T administration (group T-M). Otherwise, treatment of hepatotoxicity using $\mathrm{M}$ and $\mathrm{E}$ showed less effectiveness than the treatment with M or E, separately, and this indicates the presence of anti-synergistic effect between them. The administration of healthy rats with $\mathrm{M}$ for 12 weeks has no side effect.

Acknowledgements The authors wish to thank Dr. Waleed Sobhy, Histopathology Department, Faculty of Veterinary Medicine, Kafrelsheikh University, Egypt, for his cooperation in the histopathological examination.

Author contribution Nadia Z. Shaban proposed this study; planned and organized and contributed in the sequence arrangement; wrote and reviewed and approved the manuscript; and convention to be accountable for all aspects of the work to be responsible for all aspects of the work for ensuring that questions related to the accuracy or safety of any part of the work are appropriately inspected and resolved. M. M shared in the proposal of this study, shared in its design, carried out the experimental part, executed the statistical analysis, and drew the figures, and was a main contributor in writing and reviewing the manuscript. F. K. participated in supervision on the experiments. A.A. participated in read and approved the final manuscript. A. S. participated in the statistical analysis. H. participated in supervision on the experiments. All authors approved the final manuscript.

Funding Open access funding provided by The Science, Technology \& Innovation Funding Authority (STDF) in cooperation with The Egyptian Knowledge Bank (EKB).

Data availability All data generated or analyzed during this study are included in this published article.

\section{Declarations}

Ethics approval and consent to participate All animal methodology were done following the Committee of concerning the use and care of experimental animals at the Pharmaceutical \& Fermentation Industries Development Center of the general authority of the City of Scientific Research and Technological Applications (SRTA-city) in accordance with the Ethics Committee of Institutional Animal Care and Use Committee (IACUC) (ethical approval number: 37-6F-0120).

\section{Consent for publication Not applicable}

Competing interests The authors declare no competing interests. 
Open Access This article is licensed under a Creative Commons Attribution 4.0 International License, which permits use, sharing, adaptation, distribution and reproduction in any medium or format, as long as you give appropriate credit to the original author(s) and the source, provide a link to the Creative Commons licence, and indicate if changes were made. The images or other third party material in this article are included in the article's Creative Commons licence, unless indicated otherwise in a credit line to the material. If material is not included in the article's Creative Commons licence and your intended use is not permitted by statutory regulation or exceeds the permitted use, you will need to obtain permission directly from the copyright holder. To view a copy of this licence, visit http://creativecommons.org/licenses/by/4.0/.

\section{References}

Abdel-Rahman S, Shaban N, Haggag A, Awad D, Bassiouny A and Talaat I (2015) Inhibition of NF- $\mathrm{B}, \mathrm{Bcl}-2$ and $\mathrm{COX}-2$ gene expression by an extract of Eruca sativa seeds during rat mammary gland carcinogenesis. Asian Pac J Cancer Prev 16:8411-8418

Ajai A, Ochigbo S, Abdullahi Z and Anigboro P (2014) Determination of trace metals and essential minerals in selected fruit juices in Minna, Nigeria. Int J Food Sci 462931. https://doi.org/10.1155/ 2014/462931

Akhtar T, Sheikh N (2013) An overview of thioacetamide-induced hepatotoxicity. Toxin Rev 3:43-46

Carlberg I, Mannervik B (1985) [59] Glutathione reductase. Methods Enzymol, Elsevier 113:484-490

Chen J, Bhandar B and Kavdia M (2015) Interaction of ROS and RNS with GSH and GSH/GPX systems. FASEB J 1_supplement 29:636-637

Forrester SJ, Booz GW, Sigmund CD, Coffman TM, Kawai T, Rizzo V, Scalia R, Eguchi S (2018) Angiotensin II signal transduction: an update on mechanisms of physiology and pathophysiology. Physiol Rev 3:1627-1738

Friedman SL (1999) Cytokines and fibrogenesis. Seminars in liver disease, () 1999 by Thieme Medical Publishers, Inc. 19:pp. 129-140

Frishman WH, Cheng-Lai A, Nawarskas J (2005) Current cardiovascular drugs, Springer Science \& Business Media pp. 246

Gornall AG, Bardawill CJ, David MM (1949) Determination of serum proteins by means of the biuret reaction. J Biol Chem 2:751-766

Habashy NH, Serie MMA, Attia WE, Abdelgaleil SA (2018) Chemical characterization, antioxidant and anti-inflammatory properties of Greek Thymus vulgaris extracts and their possible synergism with Egyptian Chlorella vulgaris. J Funct Foods 40:317-328

Habig WH, Pabst MJ, Jakoby WB (1974) Glutathione S-transferases the first enzymatic step in mercapturic acid formation. J Biol Chem 22:7130-7139

Habtemariam S (1997) Flavonoids as inhibitors or enhancers of the cytotoxicity of tumor necrosis factor-R in L-929 tumor cells. J Nat Prod 60:775-778

Hayakawa M, Kuzuya F (1990) Free radicals and diabetes mellitus. Nihon Ronen Igakkai zasshi. Jpn J Geriatr 2:149-154

Hesari M, Mohammadi P, Khademi F, Shackebaei D, Momtaz S, Moasefi N, Farzaei MH, Abdollahi M (2021) Current advances in the use of nanophytomedicine therapies for human cardiovascular diseases. Int J Nanomed 16:3293

Higgins LG, Hayes JD (2011) Mechanisms of induction of cytosolic and microsomal glutathione transferase (GST) genes by xenobiotics and pro-inflammatory agents. Drug Metab Rev 2:92-137
Islam MS, Akhtar MM, Ciavattini A, Giannubilo SR, Protic O, Janjusevic M, Procopio AD, Segars JH, Castellucci M, Ciarmela P (2014) Use of dietary phytochemicals to target inflammation, fibrosis, proliferation, and angiogenesis in uterine tissues: promising options for prevention and treatment of uterine fibroids? Mol Nutr Food Res 8:1667-1684

Jaeschke H, Gores GJ, Cederbaum AI, Hinson JA, Pessayre D, Lemasters JJ (2002) Mechanisms of hepatotoxicity. Toxicol Sci 2:166-176

Kim H, Moon JY, Kim H, Lee D-S, Cho M, Choi H-K, Kim YS, Mosaddik A, Cho SK (2010) Antioxidant and antiproliferative activities of mango (Mangifera indica L.) flesh and peel. Food Chem 2:429-436

Koolman J, Röhm K-H (2005) Bioquímica: texto y atlas, 3ra. Madrid: Ed. Médica Panamericana 52:72-76

Labiós M, Martínez M, Gabriel F, Guiral V, Ruiz-Aja S, Beltrán B, Munoz A (2008) Effects of eprosartan on mitochondrial membrane potential and $\mathrm{H} 2 \mathrm{O} 2$ levels in leucocytes in hypertension. J Hum Hypertens 7:493-500

Lauricella M, Emanuele S, Calvaruso G, Giuliano M and D'Anneo A (2017) Multifaceted health benefits of mangifera indica L.(Mango): the inestimable value of orchards recently planted in sicilian rural areas. Nutrients 9:525

Livak KJ and Schmittgen TD (2001) Analysis of relative gene expression data using real-time quantitative PCR and the $2-\Delta \Delta \mathrm{CT}$ method. methods 4:402-408

López D, Pavelkova M, Gallova L, Simonetti P, Gardana C, Lojek A, Loaiza R, Mitjavila M (2007) Dealcoholized red and white wines decrease oxidative stress associated with inflammation in rats. $\mathrm{Br}$ J Nutr 3:611-619

Lucas EA, Li W, Peterson SK, Brown A, Kuvibidila S, Perkins-Veazie P, Clarke SL, Smith BJ (2011) Mango modulates body fat and plasma glucose and lipids in mice fed a high-fat diet. Br J Nutr 10:1495-1505

Ma X, Wu H, Liu L, Yao Q, Wang S, Zhan R, Xing S, Zhou Y (2011) Polyphenolic compounds and antioxidant properties in mango fruits. Sci Hortic 1:102-107

Malloy HT, Evelyn KA (1937) The determination of bilirubin with the photoelectric colorimeter. J Biol Chem 2:481-490

Masibo M, He Q (2009) Mango bioactive compounds and related nutraceutical properties-a review. Food Rev Int 4:346-370

Mehra P, Koul A, Bansal DD (2013) Studies on antioxidant role of (+)-catechin hydrate in high sucrose high fat diet induced oxidative stress. Am J Biomed Sci 5:161-170

Michiels C, Raes M, Toussaint O, Remacle J (1994) Importance of Seglutathione peroxidase, catalase, and $\mathrm{Cu} / \mathrm{Zn}-\mathrm{SOD}$ for cell survival against oxidative stress. Free Radic Biol Med 3:235-248

Morsy MA, Heeba GH and Mahmoud ME (2015) Ameliorative effect of eprosartan on high-fat diet/streptozotocin-induced early diabetic nephropathy in rats. Eur J Pharmacol 750:90-97

Ohkawa H, Ohishi N, Yagi K (1979) Assay for lipid peroxides in animal tissues by thiobarbituric acid reaction. Anal Biochem 2:351-358

Ooi DJ, Chan KW, Sarega N, Alitheen NB, Ithnin H, Ismail M (2016) Bioprospecting the curculigoside-cinnamic acid-rich fraction from Molineria latifolia rhizome as a potential antioxidant therapeutic agent. Molecules 6:682

Paglia DE, Valentine WN (1967) Studies on the quantitative and qualitative characterization of erythrocyte glutathione peroxidase. $\mathrm{J}$ Lab Clin Med 1:158-169

Palacios RS, Roderfeld M, Hemmann S, Rath T, Atanasova S, Tschuschner A, Gressner OA, Weiskirchen R, Graf J, Roeb E 
(2008) Activation of hepatic stellate cells is associated with cytokine expression in thioacetamide-induced hepatic fibrosis in mice. Lab Investig 11:1192-1203

Pandey KB, Rizvi SI (2009) Plant polyphenols as dietary antioxidants in human health and disease. Oxidative Med Cell Longev 5:270-278

Park H-J, Kim H-G, Wang J-H, Choi M-K, Han J-M, Lee J-S, Son C-G (2016) Comparison of TGF- $\beta$, PDGF, and CTGF in hepatic fibrosis models using DMN, CCl4, and TAA. Drug Chem Toxicol $1: 111-118$

Prieto P, Pineda M, Aguilar M (1999) Spectrophotometric quantitation of antioxidant capacity through the formation of a phosphomolybdenum complex: specific application to the determination of vitamin E. Anal Biochem 2:337-341

Rajman L, Chwalek K, Sinclair DA (2018) Therapeutic potential of NAD-boosting molecules: the in vivo evidence. Cell Metab 3:529-547

Ray PD, Huang B-W, Tsuji Y (2012) Reactive oxygen species (ROS) homeostasis and redox regulation in cellular signaling. Cell Sig 5:981-990

Reitman S, Frankel S (1957) A colorimetric method for the determination of serum glutamic oxalacetic and glutamic pyruvic transaminases. Am J Clin Pathol 1:56-63

Rejitha S, Prathibha P, Indira M (2012) Amelioration of alcoholinduced hepatotoxicity by the administration of ethanolic extract of Sida cordifolia Linn. Br J Nutr 7:1256-1263

Rodes J, Benhamou J-P, Blei A, Reichen J, Rizzetto M (2008) The textbook of hepatology: from basic science to clinical practice, Wiley-Blackwell 3rd ed. P 89-128

Rodríguez-Fragoso L, Reyes-Esparza J (2013) Fruit/vegetable-drug interactions: effects on drug metabolizing enzymes and drug transporters. Drug Discovery; IntechOpen: London, UK:1-33

Saed GM, Diamond MP, Fletcher NM (2017) Updates of the role of oxidative stress in the pathogenesis of ovarian cancer. Gynecol Oncol 3:595-602

Santana-Gálvez J, Cisneros-Zevallos L, Jacobo-Velázquez DA (2017) Chlorogenic acid: recent advances on its dual role as a food additive and a nutraceutical against metabolic syndrome. Molecules 3:358

Sanz N, Díez-Fernández C, Andrés D, Cascales Ma (2002) Hepatotoxicity and aging: endogenous antioxidant systems in hepatocytes from 2-, 6-, 12-, 18-and 30-month-old rats following a necrogenic dose of thioacetamide. Biochim Biophys Acta (BBA) Mol Basis Dis 1:12-20

Sedlak J, Lindsay RH (1968) Estimation of total, protein-bound, and nonprotein sulfhydryl groups in tissue with Ellman's reagent. Anal Biochem 25:192-205

Shaban NZ, Aboelsaad AM, Awad D, Abdulmalek SA, Shaban SY (2022). Therapeutic effect of dithiophenolato chitosan nanocomposites against carbon tetrachloride-induced hepatotoxicity in rats. Environ Sci Pollut Res. 29:8487-8502

Shaban NZ, Abd El-Kader SE, Mogahed FA, El-Kersh MA, Habashy NH (2021a) Synergistic protective effect of Beta vulgaris with meso-2, 3-dimercaptosuccinic acid against lead-induced neurotoxicity in male rats. Sci Rep 11(1):1-18

Shaban NZ, Abdel-Rahman S, Haggag A, Awad D, Bassiouny A, Talaat I (2016) a) Combination between taxol-encapsulated liposomes and Eruca sativa seed extract suppresses mammary tumors in female rats induced by 7, 12 Dimethylbenz $(\alpha)$ anthracene. Asian Pac J Cancer Prev 1:117-123

Shaban NZ, Abdelrahman SA, El-Kersh MA, Mogahed FA, Talaat IM, Habashy NH (2020) The synergistic hepatoprotective potential of Beta vulgaris juice and 2,3-dimercaptosuccinic acid in lead-intoxicated rats via improving the hepatic oxidative and inflammatory stress. BMC Complement Med Ther 1:1-15

Shaban NZ, El-Kersh MA, Bader-Eldin MM, Kato SA, Hamoda AF (2014) Effect of Punica granatum (pomegranate) juice extract on healthy liver and hepatotoxicity induced by diethylnitrosamine and phenobarbital in male rats. J Med Food 3:339-349

Shaban NZ, El-Kersh MA, El-Rashidy FH, Habashy NH (2013) Protective role of Punica granatum (pomegranate) peel and seed oil extracts on diethylnitrosamine and phenobarbital-induced hepatic injury in male rats. Food Chem 3:1587-1596

Shaban NZ, Hegazy W, Abdel-Rahman S, Awed O and Khalil S (2016b) Potential effect of Olea europea leaves, Sonchus oleraceus leaves and Mangifera indica peel extracts on aromatase activity in human placental microsomes and CYP19A1 expression in MCF-7 cell line: Comparative study. Cell Mol Biol (Noisy-le-Grand, France) 9:11-19

Shaban NZ, Helmy MH, El-Kersh MA, Mahmoud BF (2003) Effects of Bacillus thuringiensis toxin on hepatic lipid peroxidation and free-radical scavengers in rats given alpha-tocopherol or acetylsalicylate. Comp Biochem Physiol C Toxicol Pharmacol 4:405-414

Shaban NZ, Talaat I, Elrashidy F, Hegazy A, Sultan A (2017) Therapeutic role of Punica granatum (pomegranate) seed oil extract on bone turnover and resorption induced in ovariectomized rats. $\mathrm{J}$ Nutr Health Aging 10:1299-1306

Shaban NZ, Yehia SA, Awad D, Shaban SY, Saleh SR (2021) b) A titanium (IV)-dithiophenolate complex and its chitosan nanocomposite: their roles towards rat liver injuries in vivo and against human liver cancer cell lines. Int J Mol Sci 22:11219. https://doi. org/10.3390/ijms222011219

Shazia Q, Mohammad Z, Rahman T and Shekhar HU (2012) Correlation of oxidative stress with serum trace element levels and antioxidant enzyme status in Beta thalassemia major patients: a review of the literature. Anemia 2012:91-97

Suzuki H, Suzuki K (1998) Rat hypoplastic kidney (hpk/hpk) induces renal anemia, hyperparathyroidism, and osteodystrophy at the end stage of renal failure. J Vet Med Sci 10:1051-1058

Szasz G (1974) New substrates for measuring gamma-glutamyl transpeptidase activity. Z Klin Chem Klin Biochem 5:228

Taga MS, Miller E, Pratt D (1984) Chia seeds as a source of natural lipid antioxidants. J Am Oil Chem Soc 5:928-931

Tenero D, Martin D, Ilson B, Jushchyshyn J, Boike S, Lundberg D, Zariffa N, Boyle D, Jorkasky D (1998) Pharmacokinetics of intravenously and orally administered eprosartan in healthy males: absolute bioavailability and effect of food. Biopharm Drug Dispos 6:351-356

Tietz Na ML (1987) Reference ranges. Tietz NW. Fundamentals of clinical chemistry. WB Saunders Company, Philadelphia pp. $47-51$

Ulla A, Rahman MT, Habib ZF, Rahman MM, Subhan N, Sikder B, Reza HM, Hossain MH, Alam MA (2017) Mango peel powder supplementation prevents oxidative stress, inflammation, and fibrosis in carbon tetrachloride induced hepatic dysfunction in rats. J Food Biochem 3:e12344

Wallace M, Hamesch K, Lunova M, Kim Y, Weiskirchen R, Strnad P, Friedman S (2015) Standard operating procedures in experimental liver research: thioacetamide model in mice and rats. Lab Anim 49:21-9

Wickert L, Steinkrüger S, Abiaka M, Bolkenius U, Purps O, Schnabel C, Gressner A (2002) Quantitative monitoring of the mRNA expression pattern of the TGF- $\beta$-isoforms $(\beta 1, \beta 2, \beta 3)$ during transdifferentiation of hepatic stellate cells using a newly 
developed real-time SYBR Green PCR. Biochem Biophys Res Commun 2:330-335

Wong VY, Laping NJ, Contino LC, Olson BA, Grygielko E, Brooks DP (2000) Gene expression in rats with renal disease treated with the angiotensin II receptor antagonist, eprosartan. Physiol Genomics $1: 35-42$
Zhou J-R, Blackburn GL, Walker WA (2007) Symposium introduction: metabolic syndrome and the onset of cancer. Am J Clin Nutr 3:817S-819S

Zou Y, Lu Y, Wei D (2004) Antioxidant activity of a flavonoid-rich extract of Hypericum perforatum L. in vitro. J Agric Food Chem 16:5032-5039

Publisher's note Springer Nature remains neutral with regard to jurisdictional claims in published maps and institutional affiliations.

\section{Authors and Affiliations}

\section{Nadia Zaki Shaban ${ }^{1}$ (1) Mohammad Mohammad Zaki ${ }^{1,2} \cdot$ Fayed Koutb $^{3} \cdot$ Ahmed Alaa Abdul-Aziz $^{4}$. Ashraf Abdul-Hamid Elshehawy ${ }^{2} \cdot$ Hany Mehany ${ }^{2}$}

$\triangle$ Nadia Zaki Shaban

nshaban2001@Yahoo.co.uk

1 Biochemistry Department, Faculty of Science, Alexandria University, Alexandria, Egypt

2 Chemistry Department, Faculty of Science, Kafrelsheikh University, Kafr El-Sheikh, Egypt
3 Nucleic Acid Research Department, Genetic Engineering and Biotechnology Research Institute, City of Scientific Research and Technological Applications, Alexandria, Egypt

4 Endocrinology Unit, Department of Internal Medicine, Faculty of Medicine, Alexandria University, Alexandria, Egypt 